\title{
Copaiba oleoresin: evaluation of the presence of polycyclic aromatic hydrocarbons (PAHs)
}

\author{
Wilson Gomes da Silva ${ }^{1,2, *}$ Nicoletta Cortesi², Paola Fusari ${ }^{2}$ \\ ${ }^{1}$ Faculty of Pharmaceutical Sciences, Federal University of Amazonas; \\ ${ }^{2}$ Stazione Sperimentale degli Oli e dei Grassi (SSOG), Milan, Itália
}

\begin{abstract}
The copaiba oleoresin extracted by perforating the tree-trunk found in the Amazonian forest has been used by the native indigenous communities to treat several diseases and also as fuel for lighting and for the motorboats plying the region's rivers. Currently, the oleoresin is mostly employed as a traditional remedy, mainly for the treatment of tonsillitis and as an anti-inflammatory and healing agent in oil and capsule forms, and is also used in several industry sectors. Due to its use in oral form, especially as a traditional remedy, an analysis of the presence of polycyclic aromatic hydrocarbons (PAHs) as contaminants in the oleoresin was performed. PAHs are substances formed by two or more benzoic rings and found in the atmosphere as a residue from incomplete combustion of petroleum derivatives and industrial activities. These substances are found everywhere on land and water, and as a consequence can also be found in vegetables and foodstuffs in general. The use of products contaminated with these substances can compromise human and animal life. This study was performed on oleoresin from different areas or regions in the Amazon, using the HPLC methodology with fluorescence detection. The samples analyzed revealed different concentrations of these compounds.
\end{abstract}

Uniterms. Copaiba/oil/qualitative analysis. Polycyclic aromatic hydrocarbons. High performance liquid chromatography/qualitative analysis. Amazônia/traditional remedy.

O óleo-resina de copaíba que é extraído mediante a perfuração do tronco da árvore que se encontra em forma nativa na floresta amazônica já era empregado pelas comunidades indígenas para a cura de várias doenças e, também, como combustível em iluminação e para o funcionamento de motores de barcos que trafegavam pelos rios da região. Hoje, é largamente empregado na medicina popular, principalmente para o tratamento de amigdalite e como antiinflamatório e cicatrizante na forma de óleo e em cápsulas, sendo utilizado, também, em vários setores da indústria. Devido ao seu uso na forma oral, principalmente na medicina popular, realizou-se um trabalho para avaliar a presença de hidrocarbonetos policíclicos aromáticos (HPAs) no referido óleo-resina, como possíveis contaminantes. Os HPAs são compostos formados por dois ou mais aneis benzenicos e encontrados na atmosfera como resíduos provenientes das combustões incompletas dos derivados de petróleo e de atividades industriais. Esses compostos, preciptando-se da atmosfera, atingem terrenos, fontes de água e, consequentemente, os vegetais e gêneros alimentícios em geral. O uso de produtos contaminados com os sudetos compostos pode comprometer vidas humanas e animais. O estudo foi realizado com amostras do referido óleo-resina provenientes de diferentes áreas ou regiões da Amazônia, empregando-se a metodologia HPLC com detecção através de fluorescência.

Unitermos: Copaíba/ óleo/ análise qualitativa. Hidrocarbonetos policíclicos aromáticos. Cromatografia líquida de alta eficiência/análise qualitativa. Amazônia/medicina popular.

\section{INTRODUCTION}

The copaiba tree is found in the Brazilian states of Amazonas, Pará, Ceará, Mato Grosso and Paraná. The li-

*Correspondence: W. G. Silva. Stazione Sperimentale Degli Oli e dei Grassi (SSOG), V. G. Colombo, 79 - 20133 - Milão, Itália. E-mail: 037134100@iol.it terature describes 72 species and 16 have been catalogued in Brazil. The species are differentiated by the size of the trees, flower characteristics, wood densities, viscosity and color of the oleoresins present in the plant. Colors vary from light yellow to reddish brown, depending on the age of the plant and on the species. The oleoresins have 
a strong aroma and acidic taste. The preferential method of extraction is using an instrument known as an auger, which perforates the copaiba tree trunk without damaging it. The oil that runs from the secretion channels through the holes is collected in small containers set against the tree trunks. The oil is then transferred to larger containers and eventually to drums for shipping. After collection, the holes are closed with bungs of wood from the same tree plus clay, allowing for regeneration and continuing oleoresin production. Another frequently used method, which is more aggressive and less environmentally friendly, entails cutting down the tree. Once the oil has run down from the channels in the tree, the wood is sold (Le Cointe, 1947; Loureiro et al., 1979; Berg van den, 1982; Castro da Costa et al., 1990; Cruz, 1995; Veiga Junior, Pinto Carlos, 2002).

Given the heterogeneity of the forest and the difficulty in selecting the copaiba trees by species for oleoresin extraction, the oleoresins found in the commercial areas of Manaus are a mixture of various species, particularly those predominant in Amazonas: C. officinale L., C. Reticulata ducke and C. langsdorffii Desf. (Veiga Junior, Pinto Carlos, 2002).

Veiga Junior and Pinto Carlos reported that botanists and chroniclers in previous centuries (1534) previously displayed knowledge on the uses of copaiba oleoresin. Petrus Martius published reports on the use of oleoresin by the natives of the Amazon in Strasbourg, and at the same time, a translation of the publication by the Jesuit Priest José Costa emerged, stating: the balsam is celebrated with good reason, based on the excellent aroma and even more so based on the healing effect on wounds and other infirmities. In time, and given the increase in interest in this oil, the product has become increasingly disseminated and used as a traditional remedy for curing several diseases: for treating tonsillitis, as an anti-inflammatory, as an antiseptic in the urinary tract, as a sedative and expectorant as well as for healing wounds and ulcers. It is also reported as being used in the treatment of some types of tumors and in industry sectors such as cosmetics, paints, varnishes and photography (Veiga Junior, Pinto Carlos, 2002).

Copaiba oil is often adulterated by mixing with other vegetable oils of lesser commercial value for economic reasons, or even contaminated by residue from the washing of the containers used for extraction, transport and commercialization (Veiga Junior, Pinto Carlos, 2002).

In the past, the oil was also used as fuel for the internal combustion motorboat engines that were used on the Amazon rivers, and finally as fuel for lighting in general, and specifically to light the lamp torches that were used to collect rubber during the evening (cautchu). Nowadays, besides the frequent use of the oleoresin as a traditional remedy in various communities mainly in the states of Amazonas and Pará, it is also transported to other Brazilian states and exported to countries such as the U.S.A, Germany, France and England. Exports are estimated at hundreds of tons per year (Berg, 1982; Castro da Costa et al., 1990; Cruz, 1995; Veiga Junior, Pinto Carlos, 2002).

The literature describes the presence of the hydrocarbons sesquiterpenes and diterpenes in the oleoresin, outlining that 28 constituent substances are of the caurane, clerodane and labdan diterpene classes (Veiga Junior, Pinto Carlos, 2002). However, there is no reference to polycyclic aromatic hydrocarbons (PAHs).

The impact of the emissions of petroleum derivatives on public health and the toxicological effects in populations are current worrying and priority issues globally. Polycyclic aromatic hydrocarbons (PAHs) constantly released into the atmosphere due to incomplete combustion of diesel oil and gasoline in internal combustion engines, developed at relatively high temperatures and at low oxygen content, are recognized for their toxicity among chemical substances with high toxic effect (Pereira et al., 2000; Guimarães, 2004; Avella, Faedo, 2006; Bolzacchini et al., 2006; EFSA, 2008).

Polycyclic aromatic hydrocarbons are solid substances at room temperature, possess low solubility in water and degrade in the presence of ultraviolet radiation (Pereira et al., 2000; Guimarães, 2004).

The toxicological effects on the human body occur due to inhalation, depositing on the skin, consumption of contaminated foods and of particulate matter present in the atmosphere which precipitates to the ground and water and thereby contaminates foodstuffs, principally leafy vegetables, cereals and other types of vegetables also used in traditional medicine.

The physical and chemical properties of the substances discussed above, and the high incidence of these substances in the environment, can compromise human health. As a result of their lipophillic affinity and their minuscule particles ( $<1$ millimicrons), they are easily absorbed by the body. Several polycyclic aromatic hydrocarbon substances and its derivatives act directly on the human body or metabolically transform DNA via biochemical mechanisms, rendering them carcinogenic and mutagenic (Morrison, Boyd, 1961; Lee et al., 1981; Pereira et al., 2000; Veiga Junior, Pinto Carlos, 2002, Guimarães, 2004; Cortesi et al., 2006 ; Appa-Agf-Trento, 2007).

According to the World Health Organization (WHO), nine out of 100,000 people exposed to a concentration of $1 \mathrm{ng} / \mathrm{m}^{3}$ of benzo(a)pyrene are subject to cancer, where an estimated 6.5 million people die yearly 
of carcinogenic diseases (Appa-Agf-Trento, 2007; Pereira et al., 2000; Guimarães, 2004).

Other sources of anthropic polycyclic aromatic hydrocarbons include petrol refineries, aluminum production, coke gasification, refuse incineration, vulcanization, boilers, and foods submitted to high temperature drying and smoking (Pereira et al. 2000; Guimarães, 2004; AppaAgf-Trento, 2007). Besides the anthropic sources outlined, polycyclic aromatic hydrocarbon sources can also be found in nature, such as volcanic eruptions, savanna and forest fires. They can also be formed via biosynthesis in some plants and microorganisms. Based on their molecular weight they can be classified as light or heavy. The literature rates as light those that have two to four benzoic nucleus in their chemical structure and as heavy those that have more than four (Larsen, Poulsen,1987; Cortesi, 2001; EFSA, 2008). A few examples can be seen in Table I.

TABLE I - Examples of light and heavy polycyclic aromatic hydrocarbons most frequently evaluated in environmental studies

\begin{tabular}{cc}
\hline Naphthalene & Benzo(e)pyrene \\
Acenaphthene & Benzo(b)fluoranthene \\
Fluorene & Benzo(k)fluoranthene \\
Phenanthrene & Benzo(a)pyrene \\
Anthracene & Dibenzo(a,h)anthracene \\
Fluoranthene & Benzo(g,h,i)perylene \\
Pyrene & Indeno(1,2,3)pyrene \\
Benzo(a)anthracene & Chrysene \\
\hline
\end{tabular}

The International Agency for Research on Cancer (IARC) classifies the heavy polycyclic aromatic hydrocarbons as substances which are highly toxic to the human body at the following levels: benzo(a)anthracene $2 \mathrm{~B}$, benzo(b)fluoranthene $2 \mathrm{~B}$, benzo(k)fluoranthene $2 \mathrm{~B}$, benzo(a)pyrene $2 \mathrm{~A}$, dibenzo(a,h)anthracene $2 \mathrm{~A}$ and indeno(1,2,3-cd)pyrene 2B. Nitrogenated and oxygenated polycyclic aromatic hydrocarbons have been shown to pose an increasing hazard (IARC, 1983, 1987).

The European Parliament and Council have introduced limits on atmospheric pollutants via Directive 2004/107/EC, specifying a maximum concentration of atmospheric benzo(a)pyrene of $1 \mathrm{ng} / \mathrm{m}^{3}$, also defining it as a selective and indicative marker of contamination and carcinogenic risk among the polycyclic aromatic hydrocarbons present in the atmosphere (Appa-Agf-Tn, 2007).

Current European norms as published in the Official Journal of the European Union also designate benzo(a) pyrene as a selective and indicative marker of the presence and genotoxic carcinogenic effects of other polycyclic aromatic hydrocarbon, setting the maximum limit of 2.0 $\mathrm{ng} / \mathrm{g}$ as the limit for oils and vegetable fats destined for human food (European Community Regulation N ${ }^{\circ}$ 208/2005; Commission EC Regulation $\mathrm{N}^{\circ} 1881 / 2006$ ).

Set in the context of human health, the quality of the air we breathe and the public health considerations that follow, and in light of the numerous and growing body of literature and a clear interest in increasing our knowledge about polycyclic aromatic hydrocarbons and other contaminants, this study sought to evaluate the PAHs present in Amazonian copaiba oleoresin, given that this oleoresin is used in large quantities in Brazil, mainly as a traditional remedy but also in other industries.

\section{MATERIALS AND METHODS}

\section{Materials}

The following samples were utilized:

Sample 1 - copaiba oleoresin extracted from young plants, 2006.

Sample 2 - copaiba oleoresin extracted from adult plants, 2006.

Sample 3 - copaiba oleoresin in capsule form purchased in Manaus, produced in 2006, denominated A.

Sample 4 - copaiba oleoresin in capsule form purchased in Manaus, produced in 2006, denominated B.

Sample 5 - red copaiba oleoresin extracted from plant, 2005.

The samples used in the analysis were stored at a temperature of $-18^{\circ} \mathrm{C}$.

\section{Reagents}

Acetonitrile HPLC grade, CarloErba, Italy.

Water HPLC grade, Aldrich, Germany.

Isooctane for spectometry (UV-IR-FLUO), Merck, Germany.

Cyclohexane for spectometry (UV-IR-FLUO), Carlo Erba, Italy.

Methylene chloride for chromatography, Carlo Erba, Italy.

Isopropanol HPLC grade, Carlo Erba, Italy.

\section{Columns for solid phase extraction/purification (SPE)}

Bond Elut - PPL Column, based on a styrene divinylbenzene copolymer Varian $1 \mathrm{~g}, 6 \mathrm{~mL}, 30 / \mathrm{PK}$, Superchrom, Italy. 


\section{PAH standards}

Stock PAH solution: PAH $10 \mathrm{ng} / \mu \mathrm{L}$ (PAH-Mix 9 Dr. Ehrenstorfer GmbH part no. L20950900 cyclohexane).

Benzo(e)pyrene $10 \mathrm{ng} / \mu \mathrm{L}$ (Dr. Ehrenstorfer GmbH part no. L20645000 cyclohexane).

Benzo(b)chrysene $10 \mathrm{ng} / \mu \mathrm{L}$ (Dr. Ehrenstorfer GmbH part no. L20550000 cyclohexane).

Working PAH solution external standard calibration level: 16 PAHs, Benzo(e)pyrene, Benzo(b)chrysene 2ng/mL.

\section{Equipment}

Analytical balance, precision $\pm 0.0001 \mathrm{~g}$.

Class A volumetric flasks, several volumes.

$10 \mathrm{~mL}$ graduated cone test tube.

$100 \mu \mathrm{L}$ micro syringe.

Vacuum aspiration system - Vac-Elut-Master.

Electric mixer.

Centrifuge.

\section{Chromatographic system for analysis}

High performance liquid chromatographer (HPLC) equipped with:

Programmable binary vacuum pump system P4000 (Thermo Electron Corporation).

Programmable fluorescence detector FL 3000 (Thermo Electron Corporation).

Thermostating column oven TC2000 (Service T.L.).

Analytical Lichrocart-Lichrospher column specific for analysis of PAHs $5 \mu \mathrm{m}$., 250 x $3 \mathrm{~mm}$ ID (Merck part no. 1.50156.0001).

$50 \mu \mathrm{L}$ micro syringe (Hamilton).

Electronic integration system.

\section{Sample preparation}

The previously homogenized samples were weighed on the analytical scale to $2.0 \mathrm{~g} \pm 0.001 \mathrm{~g}$, in a $10 \mathrm{~mL}$ volumetric flask. After weighing, a solution of $1 \mathrm{~mL}$ of benzo(b)chrysene (internal standard) isooctane/cyclohexane $1 / 2 \mathrm{v} / \mathrm{v}$ at $2 \mathrm{ng} / \mathrm{mL}$ concentration was added. The final volume was reached by adding isooctane/cyclohexane. The sample was then submitted to vortex for mixing.

Following this, the SPE Bond Elut - PPL columns were washed with 2 volumes of $12 \mathrm{ml}$ of methylene chloride aided by vacuum. Once dry, the columns were reconditioned with $6 \mathrm{ml}$ of isooctane/cyclohexane $1 / 2 \mathrm{v} / \mathrm{v}$ solution. The samples were transferred to the top column and $25 \mathrm{ml}$ of isooctane/cyclohexane $1 / 2 \mathrm{v} / \mathrm{v}$ were added, applying a vacuum of approximately $5 \mathrm{mmHg}$. After the columns had dried for five minutes, the removal of PAHs began, using $6 \mathrm{ml}$ of methylene chloride, collecting these in a cone test tube. The solvent was then evaporated in a nitrogen flow at room temperature. Subsequently, the sample concentrates were dissolved in $1 \mathrm{~mL}$ of acetonitrile/isopropanol $1 / 4 \mathrm{v} / \mathrm{v}$ solution and injected in the HPLC system, following a program of gradient elution at specific conditions (Cortesi et al., 2001).

\section{Operational conditions}

The analyses were performed on a HPLC system according to the conditions of the gradient elution (Cortesi et al. 2001).

Solvent A: acetonitrile and solvent B: water; Flow: $0.9 \mathrm{~mL} / \mathrm{min}$. (50\% A (0 - $5 \mathrm{~min}$.), $50-85 \% \mathrm{~A}(5$ $20 \mathrm{~min}$.), $85-90 \% \mathrm{~A}(20$ - $30 \mathrm{~min}$.), $90-100 \% \mathrm{~A}(30$ - $35 \mathrm{~min}$.).

Pressure: 160 bar;

Volume injected: $20 \mu \mathrm{L}$;

Fluorescence Program: see Scheme (Table II)

Column temperature: $30 \pm 0.1{ }^{\circ} \mathrm{C}$.

The PAHs were identified on the basis of their specific fluorescence and relative retention time (Benzo(b) chrysene as internal standard). The concentrations of the samples were calculated, according to the respective areas of the substances with an integration system, based on the external standards response factors.

TABLE II - Scheme: Fluorescence program

\begin{tabular}{lcc}
\hline Components & $\begin{array}{c}\text { Excitation } \\
\lambda(\mathrm{nm})\end{array}$ & $\begin{array}{c}\text { Emission } \\
\lambda(\mathrm{nm})\end{array}$ \\
\hline Naphthalene Acenaphtene & 280280 & 330330 \\
Fluorene & 280 & 330 \\
Phenanthrene & 250 & 374 \\
Anthracene & 250 & 374 \\
Fluoranthene & 284 & 450 \\
Pyrene & 332 & 390 \\
Benzo(a)anthracene & 284 & 410 \\
Chrysene & 284 & 410 \\
Benzo(e)pyrene & 290 & 424 \\
Benzo(b)fluoranthene & 290 & 424 \\
Benzo(k)fluoranthene & 296 & 424 \\
Benzo(a)pyrene & 296 & 424 \\
Dibenzo(a,h)anthracene & 296 & 424 \\
Benzo(g,h,i) perylene & 290 & 470 \\
Indeno(1,2,3-cd)pyrene & 290 & 470 \\
Benzo(b)chrysene I.S. & 290 & 470 \\
\hline
\end{tabular}




\section{RESULTS AND DISCUSSION}

Table III shows the light and heavy polycyclic aromatic hydrocarbons (PAHs) analyzed in the samples considered, and their respective concentrations expressed as $\mathrm{ng} / \mathrm{g}$.

It is evident that among the light polycyclic aromatic hydrocarbons, phenanthrene is the substance with the highest concentration: $186.0 \mathrm{ng} / \mathrm{g}$ (Sample 2), $103.4 \mathrm{ng} / \mathrm{g}$ (Sample 1), $41.2 \mathrm{ng} / \mathrm{g}$ (Sample 3), $33.8 \mathrm{ng} / \mathrm{g}$ (Sample 4) and $31.1 \mathrm{ng} / \mathrm{g}$ (Sample 5). Other polycyclic aromatic hydrocarbons considered light can also be found in the samples, but at lower concentrations, with the exception of Chrysene ranging from $51.1 \mathrm{ng} / \mathrm{g}$ (Sample 2) to 12.3 ng/g (Sample 5) (Table III).

The table also shows that benzo(a)pyrene, generally used as a selective marker and indicator of contamination and carcinogenic and mutagenic risk in food, is always less than $1 \mathrm{ng} / \mathrm{g}$.

The results show that the copaiba oleoresin from an adult plant (Sample 2), has the highest sum of heavy polycyclic aromatic hydrocarbons $(31.5 \mathrm{ng} / \mathrm{g})$ among all the samples analyzed. However, it is not possible to estimate whether this is a characteristic of adult plants or whether the substances referred to derive from other products normally mixed in with such oils (Veiga Junior, 2002).

The oleoresin from Sample 5, which is red in color, had the lowest levels of heavy PAHs among all the samples analyzed $(4.4 \mathrm{ng} / \mathrm{g})$.

The total PAH (light + heavy) content for all the samples analyzed ranged from $324.2 \mathrm{ng} / \mathrm{g}$ (Sample 2) to $66.0 \mathrm{ng} / \mathrm{g}$ (Sample 5) (Table III).

\section{CONCLUSIONS}

The analyzed samples of copaiba oleoresin demonstrated the presence of both light and heavy polycyclic aromatic hydrocarbons (PAHs), with from two to six benzoic rings. The quantities of each substance varied from sample to sample.

Further research is necessary in order to provide a more critical and scientifically rigorous evaluation of the presence of polycyclic aromatic hydrocarbons (PAHs) in copaiba oleoresin and their pharmacological effect. Samples should be selected according to species and plant age, obtaining the oils via proper techniques while storing them in adequate containers that avoid undesirable mixtures and contamination.

Attention must also be paid to the oxidation state of the oils, as well as their degradation products, in order to

TABLE III - Data on the composition and content of polycyclic aromatic hydrocarbons (PAHs) present in copaiba oleoresins

\begin{tabular}{lccccc}
\hline PAHs & $\begin{array}{c}\text { Sample } 1 \\
\mathrm{ng} / \mathrm{g}\end{array}$ & $\begin{array}{r}\text { Sample } \\
\mathrm{ng} / \mathrm{g}\end{array}$ & $\begin{array}{c}\text { Sample } 3 \\
\mathrm{ng} / \mathrm{g}\end{array}$ & $\begin{array}{c}\text { Sample } \\
\mathrm{ng} / \mathrm{g}\end{array}$ & $\begin{array}{c}\text { Sample } \\
\mathrm{ng} / \mathrm{g}\end{array}$ \\
\hline Naphtalene $^{1}$ & 10.5 & 9.6 & 3.5 & 8.2 & 5.4 \\
Acenaphthene $^{1}$ & $\mathrm{n.d}$ & $\mathrm{n} . \mathrm{d}$ & $<0.5$ & 2.5 & 1.1 \\
Fluorene $^{1}$ & 7.3 & 11.1 & 1.6 & 3.0 & 2.8 \\
Phenanthrene $^{1}$ & 103.4 & 186.0 & 41.2 & 33.8 & 31.1 \\
Anthracene $^{1}$ & 2.3 & 6.3 & 1.2 & 1.3 & 1.2 \\
Fluoranthene $^{1}$ & 5.0 & 3.2 & 1.7 & 6.4 & 1.4 \\
Pyrene $^{1}$ & 13.4 & 19.0 & 10.4 & 23.7 & 5.4 \\
Benzo(a)anthracene $^{1}$ & 3.0 & 6.4 & 1.9 & 2.3 & 0.9 \\
Chrysene $^{1}$ & 23.7 & 51.1 & 25.1 & 43.6 & 12.3 \\
Benzo(e)pyrene $^{2}$ & 7.1 & 28.6 & 5.1 & 5.7 & 3.3 \\
Benzo(b)fluoranthene $^{2}$ & $<0.5$ & 1.6 & $<0.5$ & 1.1 & $<0.5$ \\
Benzo(k)fluoranthene $^{2}$ & $<0.5$ & 0.5 & $<0.5$ & 0.5 & 0.5 \\
Benzo(a)pyrene $^{2}$ & $<0.5$ & 0.8 & $<0.5$ & 0.5 & 0.6 \\
Dibenzo(a,h)anthracene $^{2}$ & $<0.5$ & $<0.5$ & $<0.5$ & $<0.5$ & $<0.5$ \\
Benzo(g,h,i)perylene $^{2}$ & $<0.5$ & $<0.5$ & $<0.5$ & $<0.5$ & $<0.5$ \\
Indeno(1,2,3,c-d)pyrene $^{2}$ & $<0.5$ & $<0.5$ & $<0.5$ & $<0.5$ & $<0.5$ \\
Total PAHs (light+heavy) $^{\text {Total Heavy PAHs }}$ & 175.7 & 324.2 & 91.7 & 132.6 & 66.0 \\
\hline LOQ & 7.1 & 31.5 & 5.1 & 7.8 & 4.4 \\
\hline
\end{tabular}

LOQ= Limit of quantification $0.5 \mathrm{ng} / \mathrm{g}$

${ }^{1}$ light compounds

${ }^{2}$ heavy compounds 
ensure their safe use as a traditional remedy and in several industries.

\section{REFERENCES}

APPA-AGF-TRENTO. Idrocarburi Policiclici aromatici (IAP). Available at: $<$ www.appa-agf.net/article $>$. Accessed on: 03 jul. 2007.

AVELLA, F.; FAEDO, D. Caratterizzazione delle emissioni inquinanti e del particolato (PM10) di autoveicoli diesel e benzina. Riv. Combust Ind. Chim., v.60, p.129-80, 2006.

BERG, M. E. van den. Plantas medicinais na Amazonia. Contribuição ao seu conhecimento sistemático. Belém: CNPq/PTU, 1982. p.146-147.

BOLZACCHINI, E.; PERRONE, M. G.; POZZOLI, B.; RINDONE, B. Composti organici e inorganici Nei particolato urbano milanese. Riv. Combust Ind. Chim., v.60, p.181-209, 2006.

CASTRO DA COSTA, P. R. Plantas medicinais aclimatadas da região amazonica. Manaus: Governo do Estado do Amazonas - Casa Civil, 1990. p.61.

COMMISSION EC REGULATION N ${ }^{\circ} 1881 / 2006$ of 19 dic. 2006. G. U - C. E dell'Unione Europea, 20 dic. 2006, p.L.364-365.

CORTESI, N; FUSARI, P.; ROVELLINI, P. Idrocarburi policiclici aromatici:determinazione quantitativa in matrici lipidiche. Riv. Ital. Sostanze Grasse, v.78, p.75-83, 2001.

CORTESI, N.; FUSARI, P.; GIGLIOTTI, C. Indagine quadriennale sulla contaminazione da idrocarburi Policiclici aromatici in oli di oliva e valutazione del contenuto del benzo(a)pirene come indicatore della loro presenza. Riv. Ital. Sostanze Grasse, v.83, p.151-156, 2006.

CRUZ, G. L. Dicionário das plantas úteis do Brasil. 5.ed. Rio de Janeiro: Bertland Brasil,1995. p.294-295.

EUROPEAN COMMUNITY REGULATION N ${ }^{\circ}$ 208/05. $G$. $U$ - C. E dell'Unione Europea, 04 feb. 2005, p.L.34 -35.

EUROPEAN FOOD SAFETY AUTHORITY(EFSA). Polycyclic aromatic hydrocarbons in food scientific opinion of the panel on contaminants in the food chain. The EFSA Journal, v.724 p.1-114, 2008.
FREITAS, J. R. G. P. Toxicologia das emissões veicolares de diesel: um problema de saúde ocupacional e pública. Rev. Estud. Ambient., v.6, p.82-94, 2004.

INTERNATIONAL AGENCY FOR RESEARCH ON CANCER. IARC. Monographs on the evaluation of carcinogenic risk of chemical to humans: polynuclear aromatic compounds. Lion: IARC, 1983. v.32-35, Part 1-4. Available at: <www.monographs.iarc.fr.net/article>. Accessed on: 08 jun. 2007.

INTERNATIONAL AGENCY FOR RESEARCH ON CANCER. IARC. Monographs on the evaluation of carcinogenic risk to humans. suppl. 7, v.1-42, 1987. Available at: <www.monographs.iarc.fr.net/article>. Accessed on: 09 jun. 2007.

LARSEN, J. C.; POULSEN, E. Toxicological aspects of food. London: Elsevier Applied Science, 1987. p.205-212.

LE COINTE, P. Árvores e plantas úteis indígenas aclimatadas. Amazonia Brasileira III. 2.ed. São Paulo: Biblioteca Pedagógica Brasileira, 1947. p.171.

LEE, M. L.; NOVOTNY, M. V.; BARTLE, K. D. Analytical chemistry of polycyclic aromatic compound. London: Academic Press, 1981. p.24-25.

LOUREIRO, A. A.; SILVA, M. F.; ALENCAR, C. J. Essenciais madereiras da Amazonia. Manaus: Instituto Nacional de Pesquisa do Amazonas (INPA-AM), 1979. p.133-135.

MORRISON, R.; BOYD, R. Quimica orgânica. Lisboa: Fundação Calouste Gulbenkian, 1961. p.33, p.282-283, p.922-952.

PEREIRA NETO, A. D.; MOREIRA, J. C.; DIAS, A. E.; ARBILLA, G.; FERREIRA, L. F. V.; OLIVEIRA, A. S.; BAREK, J. Avaliação da contaminação humana por hidrocarbonetos policiclicos aromáticos (HPAs) e seus derivados nitratos (NHPAS): uma revisão metodologica. Quim. Nova, v.23, n.6, p.765-773, 2000

VEIGA JUNIOR, V. F.; PINTO, A. C. O. Genero Copaifera L. Quim. Nova, v.25, n.2, p.273-286, 2002.

Received for publication on $24^{\text {th }}$ June 2008 Accepted for publication on $25^{\text {th }}$ June 2009 